\title{
Working
}

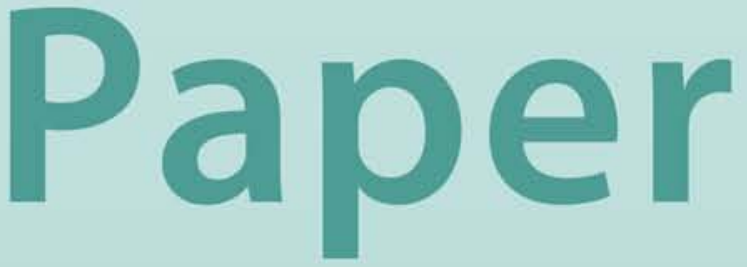


Official Dollarization as a Monetary Regime: Its Effects on El Salvador

\author{
Andrew Swiston
}




\title{
IMF Working Paper
}

Western Hemisphere Department

\section{Official Dollarization as a Monetary Regime: Its Effects on El Salvador}

Prepared by Andrew Swiston

\author{
Authorized for distribution by Marco Piñón
}

June 2011

\begin{abstract}
*
This paper examines El Salvador's transition to official dollarization by comparing aspects of this regime to the fixed exchange rate regime prevailing in the 1990s. Commercial bank interest rates are analyzed under an uncovered interest parity framework, and it is found that dollarization lowered rates by 4 to 5 percent by reducing currency risk. This has generated net annual savings averaging $1 / 2$ percent of GDP for the private sector and $1 / 4$ percent of GDP for the public sector (net of the losses from foregone seigniorage). Estimated Taylor rules show a strong positive association between Salvadoran output and U.S. Federal Reserve policy since dollarization, implying that this policy has served to stabilize economic activity more than it did under the peg and more than policy rates in Central American countries with independent monetary policy have done. Dollarization does not appear to have affected the transmission mechanism, as passthrough of monetary policy to commercial interest rates has been similar to pass-through under the peg and in the rest of Central America.
\end{abstract}

JEL Classification Numbers: E42, E43, E52, E65

Keywords: dollarization; Taylor rule; monetary policy transmission; interest rate pass-through; currency risk; uncovered interest parity; exchange rate regime

Author’s E-Mail Address: aswiston@imf.org

\section{This Working Paper should not be reported as representing the views of the IMF.} The views expressed in this Working Paper are those of the author(s) and do not necessarily represent those of the IMF or IMF policy. Working Papers describe research in progress by the author(s) and are published to elicit comments and to further debate.

\footnotetext{
* Thanks to Miguel Savastano, Marco Piñón, Mario Garza, Alejandro López-Mejía, Andy Wolfe, Jordi Prat, and seminar participants at the IMF for helpful comments and suggestions, Luis Aquino for providing data on the Salvadoran overnight domestic lending rate, and Svetlana Vtyurina for providing data on Panama.
} 


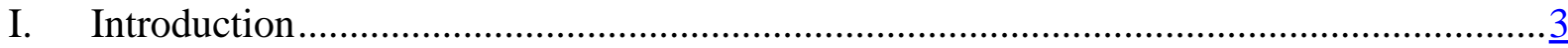

II. Dollarization and Currency Risk .............................................................................. 4

A. Deriving the Currency Risk Premium Under Uncovered Interest Parity

B. Drivers of the Currency Risk Premium Under the Peg............................................... $\underline{5}$

C. Effects of Dollarization on Nominal Interest Rates .............................................. $\underline{9}$

D. Magnitude of Foregone Seigniorage ................................................................... 11

III. Dollarization and Cyclical Stabilization .............................................................. 12

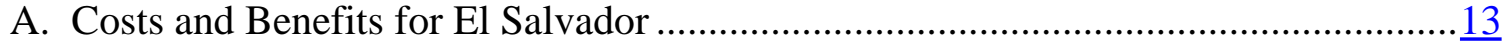

B. Cross-Country Comparisons .................................................................... 15

IV. Dollarization and Monetary Policy Transmission ................................................. 16

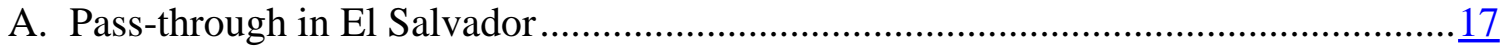

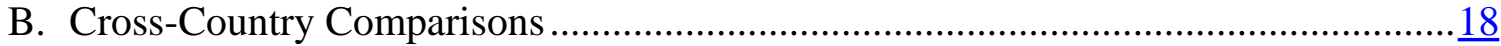

C. Factors Explaining Pass-Through ................................................................ 20

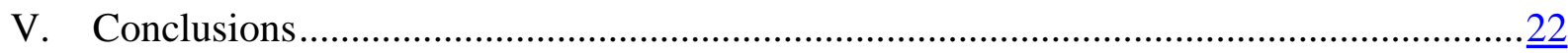

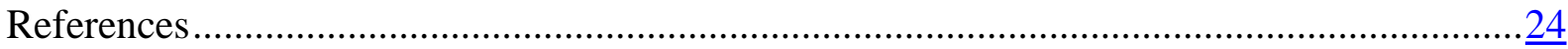

Figures

1. Interest Rates and Spreads Under the Peg .............................................................. $\underline{6}$

2. Colón-Dollar Spreads: History and Counterfactual Predictions ..................................... 10

3. Net Savings from Lower Interest Rates Under Dollarization ..................................... 10

4. Costs of Foregone Seigniorage and Benefits of Lower Interest Rates ...........................11

5. Monetary Policy Response to Inflation and Output...................................................14

6. Dollarized Economies: U.S. Monetary Policy Comovement with Inflation and Output.. $\underline{15}$

7. Central America: Monetary Policy Response to Inflation and Output ............................16

8. Interest Rate Pass-Through in Economies Using the U.S. Dollar .................................. $\frac{18}{19}$

9. Central America: Pass-Through to U.S. Dollar Interest Rates .....................................19

10. Central America: Pass-Through to Domestic Currency Interest Rates .......................... $\frac{19}{21}$

11. El Salvador and Panama: Factors Affecting the Interest Rate Gap ..............................21

Tables

1. Descriptive Statistics of Interest Rates Under the Peg.................................................. $\frac{7}{8}$

2. Determinants of Colón-Dollar Spreads Under the Peg.................................................. 8

3. Pass-Through of Monetary Policy Rate to Commercial Bank Rates..............................17

4. Factors Affecting the El Salvador-U.S. Interest Rate Gap .........................................21 


\section{INTRODUCTION}

A country's monetary regime (encompassing both monetary and exchange rate policy) forms a crucial element of its economic policy framework and is an important factor in its overall macroeconomic performance. The issue of what the optimal monetary regime is for a given country has been the subject of a great deal of theoretical and empirical analysis but has yielded no clear conclusions. ${ }^{1}$ Given the lack of consensus in the literature, country-specific circumstances are likely to play a role in determining the appropriateness of a given regime. Empirical studies on the effects of moving from one monetary regime to another, or on the performance of similar countries with different regimes, can provide evidence on this issue.

This paper analyzes the effects of official dollarization on relevant aspects of the macroeconomic performance of El Salvador. The focus is on identifying the effects of the move to dollarization from the previous monetary regime. From 1993 through 2000, El Salvador operated under a pegged exchange rate with the domestic currency of the time, the colón, trading at a rate of about 8.75 per U.S. dollar (López, 2001, describes monetary policy before official dollarization). As of January $1^{\text {st }}$, 2001, the U.S. dollar became legal tender. All wages, prices, financial accounts, and transactions were converted to U.S. dollars, and all colones were removed from circulation over a period of a few years (de García and others, 2010, discusses the transition to official dollarization).

El Salvador's decision to make the U.S. dollar its official currency was made in the context of sound macroeconomic fundamentals. Inflation was low and stable, the economy was growing, public and external debt were manageable, and there was no turmoil in the banking system. Arguments for dollarization were based on how it would tighten links to the U.S. economy and spur foreign investment, trade, and economic growth (Hinds, 1999; Hinds, 2002).

It is in this regard that this paper examines El Salvador's transition from a peg to the U.S. dollar to official dollarization. Given the similarities between the two regimes and accounting for the fact that El Salvador successfully maintained the peg from its inception until dollarization), this paper limits the scope of analysis to those areas where the effects of the monetary regime can be clearly identified. These include the effects of the monetary regime on currency risk (the perceived risk of exchange rate fluctuations), the interaction of monetary policy in the anchor country (the United States) with the business cycle in El Salvador, and the transmission of monetary policy to the rest of the economy.

\footnotetext{
${ }^{1}$ Most studies either compare officially-dollarized economies with all other economies or group them with fixed exchange rate regimes and compare with floating exchange rate regimes. Some studies suggest that floating exchange rates deliver superior macroeconomic performance (Ball, 2010; Walsh, 2009), some find that fixed exchange rates enhance performance (Frankel and Rose, 2002; Rose and Stanley, 2005), and others show no significant differences (Edwards and Magendzo, 2006; Klein, 2005), while Rogoff and others (2004) finds that performance varies depending on an economy's level of financial development and openness.
} 
This paper applies a variety of methods to quantify the effects of El Salvador's move to official dollarization. Section II uses an uncovered interest parity framework to estimate the impact of official dollarization on commercial bank interest rates through its effects in the perceived risk of devaluation and finds that this reduction in currency risk has lowered lending and deposit rates by 4 to 5 percentage points. This translates into net interest savings of about $1 / 2$ percent of GDP per year for the private sector and, once the losses from foregone seigniorage are taken into account, $1 / 4$ percent of GDP per year for the public sector.

Section III uses Taylor rules to examine the stabilization properties of monetary policy over the business cycle. Under the peg, the policy of the U.S. Federal Reserve was mildly countercyclical with respect to Salvadoran activity, while under official dollarization it has been strongly so, reflecting increased synchronization of the two economies. Federal Reserve policy since dollarization has also been more countercyclical with respect to Salvadoran growth than in other officially dollarized economies, and more countercyclical than the response of policy to output in Central American countries that have an independent monetary policy. Section IV examines the transmission of monetary policy rates to commercial bank rates. Transmission is not found to have changed significantly under dollarization and it equals or exceeds that of other officially dollarized economies and other Central American countries. Section V concludes.

\section{Dollarization AND CuRrency Risk}

This section focuses on the impact of full dollarization on the level of interest rates through its effects on the currency risk premium. The estimated net gains are then compared with the losses from foregone seigniorage.

\section{A. Deriving the Currency Risk Premium Under Uncovered Interest Parity}

Assuming uncovered interest parity holds, interest rates on instruments in domestic currency should be equal to the world interest rate plus the expected rate of depreciation of the domestic currency. This can be expressed as:

$$
b_{s}=b^{\prime \prime}+\Delta s+r p_{G}
$$

where $i_{c}$ is the interest rate in colones, $i^{*}$ is the interest rate in the United States, $\Delta s$ is the rate of expected depreciation of the domestic currency, and $r p_{c}$ is a risk premium related to other factors that would drive a wedge between the global rate of return and that demanded by investors in the domestic economy. Under both official dollarization and a fixed exchange rate, the expected value of $\Delta s$ could only be non-zero if agents perceived that there were risks of exit from the regime. Interest rates on domestic instruments denominated in U.S. dollars would be:

$$
t_{\$}=t^{*}+r p_{c}
$$


Dollarization would be expected to bring down interest rates by imposing higher exit costs, thus reducing the currency risk premium implicit in the second term of (1) and causing nominal interest rates to converge toward U.S. dollar interest rates, abstracting away from other factors. Schmukler and Servén (2002) apply this logic to test the determinants of currency risk for Argentina and Hong Kong under currency boards.

The existence of Salvadoran interest rate data in U.S. dollars and colones for otherwisehomogenous instruments allows currency risk under the peg to be estimated. Data on domestic lending and deposit rates in both U.S. dollars and colones is available monthly from 1995 through 2000 across a broad range of the same maturities. Given that these rates are from the same group of financial institutions, other factors, such as sovereign risk or bank capital constraints, should affect dollar and colón rates similarly. ${ }^{2}$

The spread between colón and U.S. dollar interest rates is calculated by subtracting (2) from (1), which yields:

$$
b_{s}-t_{\$}=\Delta s
$$

This is an approximate measure of the currency risk premium implicit in the level of interest rates in colones under the peg.

\section{B. Drivers of the Currency Risk Premium Under the Peg}

During the peg, the colón-dollar interest rate spread averaged over 5 percentage points, with substantial variation over time. Figure 1 shows interest rates in colones and U.S. dollars, as well as the spread between the two rates, for the 1995-2000 period, for 30-day, 90-day, and 180-day deposits and for loans of up to one year. ${ }^{3}$ Deposit interest rates and colón-dollar spreads were highly correlated across maturities. Colón rates rose in 1995 and peaked at 16 to 18 percent in early 1996 before dropping by 5 to 6 percentage points over the next year. They increased moderately in 1997, then fell back in the first half of 1998 before rising again in 1999. Rates fell by 4 percentage points in 2000, as talk of dollarization began to mount (see Economist, 2000; von Furstenberg, 2000; Hinds, 1999; Sachs and Larraín, 1999; and Peterson, 1999); this period is thus excluded from the empirical analysis as the expectation that financial instruments in colones would be converted to U.S. dollars could have contaminated the interest rate differential. Variation in the spreads was driven heavily by colón interest rates, as U.S. dollar rates were relatively stable throughout this period (Table 1). Correlations between the spread and the former average more than 0.9 , while correlations between the spread and the latter average less than 0.5 .

\footnotetext{
${ }^{2}$ Differences in reserve requirements across currencies could introduce a wedge between interest rates in colones and U.S. dollars, but they were not changed frequently during the period under analysis. The empirical analysis tests for differences in liquidity constraints across currencies and does not find them to be significant.

${ }^{3}$ These are the most common instruments; the behavior of rates and spreads at other maturities was similar.
} 
Figure 1. Interest Rates and Spreads Under the Peg
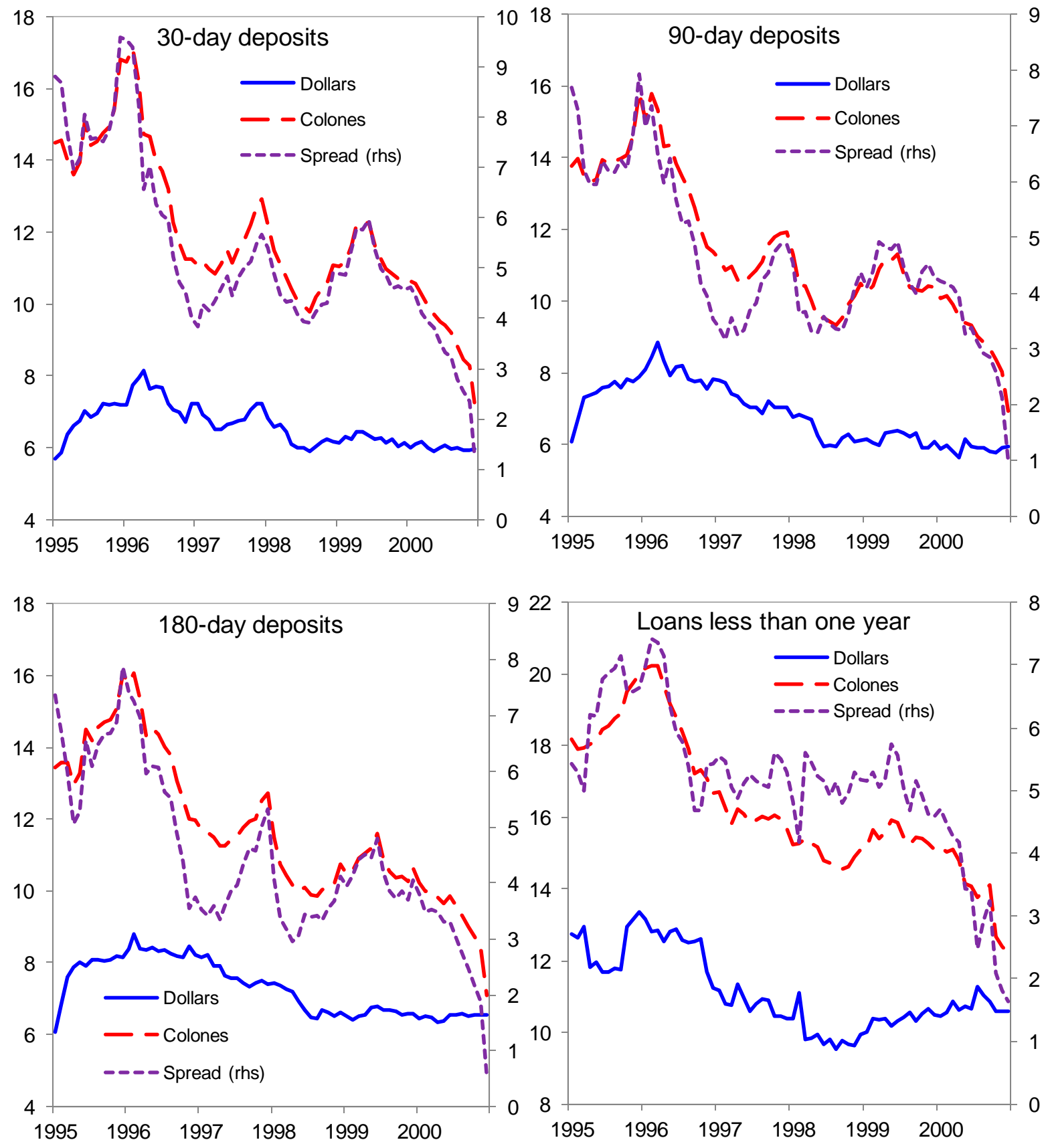

Sources: Central Reserve Bank of El Salvador; and Author's calculations. 
Table 1: Descriptive Statistics of Interest Rates Under the Peg 1/

\begin{tabular}{lccccc}
\hline & Mean & $\begin{array}{c}\text { Standard } \\
\text { deviation }\end{array}$ & $\begin{array}{c}\text { Coefficient of } \\
\text { variation 2/ }\end{array}$ & $\begin{array}{c}\text { Correlation with } \\
\text { colón rate }\end{array}$ & $\begin{array}{c}\text { Correlation with } \\
\text { dollar rate }\end{array}$ \\
\hline $\begin{array}{l}\text { Interest rates on Colón -denominated instruments } \\
\text { 30-day deposits }\end{array}$ & & & & & \\
90-day deposits & 12.45 & 1.91 & 15.37 & $\ldots$ & 0.64 \\
180-day deposits & 11.88 & 1.81 & 15.22 & $\ldots$ & 0.77 \\
Loans up to one year & 11.73 & 2.01 & 17.11 & $\ldots$ & 0.76 \\
& 16.28 & 1.93 & 11.87 & $\ldots$ & 0.93 \\
Interest rates on dollar-denominated instruments & & & & & \\
30-day deposits & 6.71 & 0.56 & 8.39 & 0.64 & $\ldots$ \\
90-day deposits & 7.03 & 0.79 & 11.26 & 0.77 & $\ldots$ \\
180-day deposits & 7.45 & 0.73 & 9.85 & 0.76 & $\ldots$ \\
Loans up to one year & 11.20 & 1.15 & 10.28 & 0.93 & $\ldots$ \\
& & & & & \\
Colón -dollar spreads & & & & & \\
30-day deposits & 5.74 & 1.62 & 28.14 & 0.96 & 0.40 \\
90-day deposits & 4.84 & 1.29 & 26.74 & 0.92 & 0.47 \\
180-day deposits & 4.76 & 1.34 & 28.24 & 0.93 & 0.47 \\
Loans up to one year & 5.55 & 0.78 & 14.10 & 0.84 & 0.57 \\
\hline
\end{tabular}

Sources: Central Reserve Bank of El Salvador; and Author's calculations.

1/ January 1995 to December 1999.

2/ Standard deviation in percent of mean.

Variation in the colón-dollar interest rate spread is likely to have been empirically related to several factors that typically affect currency risk. These factors include:

- $\quad$ External sustainability: The level of net international reserves (NIR) is the key determinant of the sustainability of a peg (Krugman, 1979; Flood and Garber, 1984). Fluctuations in the trade balance and related variables such as remittances could also affect the equilibrium real exchange rate and thus the expected probability of devaluation (Chami and others, 2008).

- $\quad$ Fiscal sustainability: Variables related to fiscal sustainability could affect the expected probability of a devaluation related to financing of the fiscal deficit through the expected future growth of the domestic money supply (Aizenman and others, 2005; Doblas-Madrid, 2009).

- $\quad$ Monetary variables: Shifts in the supply of colones relative to U.S. dollars, as reflected in the rate of growth of monetary and credit aggregates, would affect the shadow relative price between the two currencies and thus the expected probability of devaluation (Van Poeck and others, 2007). 
- $\quad$ Real factors: Productivity growth or inflation would be expected to affect the equilibrium real or nominal exchange rate, respectively, and thus the expected probability of devaluation (Lee and others, 2008; Taylor and Taylor, 2004). ${ }^{4}$

Table 2. Determinants of Colón-Dollar Spreads Under the Peg

\begin{tabular}{|c|c|c|c|c|c|c|c|c|}
\hline \multicolumn{5}{|c|}{ Dependent variable: premium on instruments denominated in colones } & \multicolumn{4}{|c|}{ versus dollar-denominated instruments } \\
\hline & \multicolumn{2}{|c|}{ 30-day deposits } & \multicolumn{2}{|c|}{ 90-day deposits } & \multicolumn{2}{|c|}{ 180-day deposits } & \multicolumn{2}{|c|}{$\begin{array}{c}\text { Loans up to one } \\
\text { year }\end{array}$} \\
\hline Credit growth (lagged) & $\begin{array}{r}0.040 \\
(0.010)\end{array}$ & 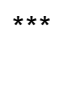 & $\begin{array}{r}0.026 \\
(0.007)\end{array}$ & *** & $\begin{array}{r}0.028 \\
(0.008)\end{array}$ & $* \star \star$ & $\begin{array}{r}0.025 \\
(0.007)\end{array}$ & $\star \star \star *$ \\
\hline Reserve growth (lagged) & $\begin{array}{r}-0.011 \\
(0.004)\end{array}$ & ** & $\begin{array}{l}-0.009 \\
(0.003)\end{array}$ & $* * *$ & $\begin{array}{r}-0.010 \\
(0.003)\end{array}$ & $* \star \star$ & $\begin{array}{l}-0.006 \\
(0.003)\end{array}$ & * \\
\hline Economic growth & $\begin{array}{r}-0.296 \\
(0.206)\end{array}$ & & $\begin{array}{l}-0.361 \\
(0.130)\end{array}$ & $\star \star * \star$ & $\begin{array}{l}-0.314 \\
(0.149)\end{array}$ & ** & $\begin{array}{l}-0.186 \\
(0.132)\end{array}$ & \\
\hline Inflation (lagged) & $\begin{array}{r}0.019 \\
(0.015)\end{array}$ & & $\begin{array}{r}0.013 \\
(0.013)\end{array}$ & & $\begin{array}{r}0.031 \\
(0.015)\end{array}$ & ** & $\begin{array}{r}0.031 \\
(0.014)\end{array}$ & ** \\
\hline Lagged dependent variable & $\begin{array}{r}0.717 \\
(0.067)\end{array}$ & $\star \star * *$ & $\begin{array}{r}0.724 \\
(0.053)\end{array}$ & 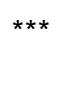 & $\begin{array}{r}0.687 \\
(0.051)\end{array}$ & $* \star \star$ & $\begin{array}{r}0.571 \\
(0.078)\end{array}$ & $* \star *$ \\
\hline Adjusted R-squared & 0.93 & & 0.92 & & 0.91 & & 0.85 & \\
\hline Durbin-Watson stat & 1.60 & & 1.87 & & 1.83 & & 1.84 & \\
\hline
\end{tabular}

Source: Author's calculations.

Notes: Sample period is January 1995 through December 1999. Heteroskedasticity and autocorrelationadjusted standard errors are in parentheses, while ${ }^{*},{ }^{* *}$, and ${ }^{* * *}$ represent coefficients that are significant at the 10,5 , or 1 percent levels. Constant term not shown.

Table 2 presents the key results from this analysis. Growth in private sector credit and NIR, economic growth, and the rate of inflation were the main drivers of colón-dollar spreads. ${ }^{5}$ As expected, faster growth in private sector credit was associated with significantly higher spreads on loans and deposits, and faster NIR growth was associated with significantly lower spreads. A faster pace of economic growth was found to be associated with significantly lower deposit spreads and lower lending spreads, though not significantly so. A higher rate of inflation raised spreads, with the impact statistically significant for longer-term deposits and loans. These variables together explain the majority of variation in lending and deposit spreads. ${ }^{6}$

\footnotetext{
${ }^{4}$ The monthly index of economic activity is used to proxy for productivity growth, for which data are unavailable.

${ }^{5}$ Private sector credit, NIR, and the inflation rate were lagged to minimize endogeneity.

${ }^{6}$ Variables related to fiscal and external sustainability (public spending, the public sector deficit, exports, remittances, and oil prices) typically entered with the correct sign but were not found to be statistically significant, possibly because the data are noisy. The Treasury-Eurodollar spread, an indicator of U.S. dollar liquidity, was not a significant driver of colón-dollar spreads.
} 


\section{Effects of Dollarization on Nominal Interest Rates}

Given the fundamental determinants of the colón-dollar spread, a simulation was generated for 2001-09 under the counterfactual assumption that the pegged exchange rate remained in place. ${ }^{7}$ Figure 2 shows the simulated spreads based on the average of the first three columns in Table 2 for deposit rates and the fourth column for lending rates. It is estimated that the currency risk premium would have fluctuated at between 3 and 6 percentage points, with this premium peaking during the global financial crisis and domestic downturn in late 2008 and early-2009. The counterfactual spreads are in line with the historical averages and volatility over the 1995-99 period. These results suggest that adopting the U.S. dollar lowered commercial bank interest rates by an average of 4 to 5 percentage points.

Applying the reduction in spreads to private sector deposits and credit (adjusted for the proportion of both aggregates that was in foreign currency before dollarization) yields a static estimate of the non-financial private sector's losses from lower interest rates on deposits and its gains from lower rates on loans. The average net savings over the dollarization period is $1 / 2$ percent of GDP, with the largest gains in 2005-07 (Figure 3). For the public sector, the spreads are applied to deposits in the financial system outside the central bank (deposits in the central bank are assumed to have always been in dollars) and to domestic debt (which was assumed to be entirely in colones before dollarization). The average net savings is also $1 / 2$ percent of GDP and has been trending upward over time as domestic debt has risen and deposits in commercial banks have fallen. Thus, for the country as a whole the total estimated gains associated with the reduction of the currency risk premium under dollarization are on the order of 1 percent of GDP per year. Note that these calculations only include the static gains. Dynamic gains could have resulted from the impact on economic growth of the reduction in financial intermediation costs and the freeing up of resources for productive spending by the public sector.

This reduction in rates occurred independently of the reduction in U.S. interest rates in the 2000s relative to the 1990s, which would likely have been realized under either exchange rate regime. These spreads isolate the effects of moving from the colón to the dollar. To the extent that their reduction reflects a lower currency risk premium, this represents a lowering of real interest rates.

\footnotetext{
${ }^{7}$ The forecast was actually generated from the beginning of 2000. Given the dip in colón-dollar spreads in 2000 as agents perceived that official dollarization was becoming more likely, this yields a more realistic starting point for 2001 in the counterfactual scenario. Nevertheless, starting the forecast from 2001 does not substantially alter the main findings.
} 
Figure 2. Colón-Dollar Spreads: History and Counterfactual Predictions
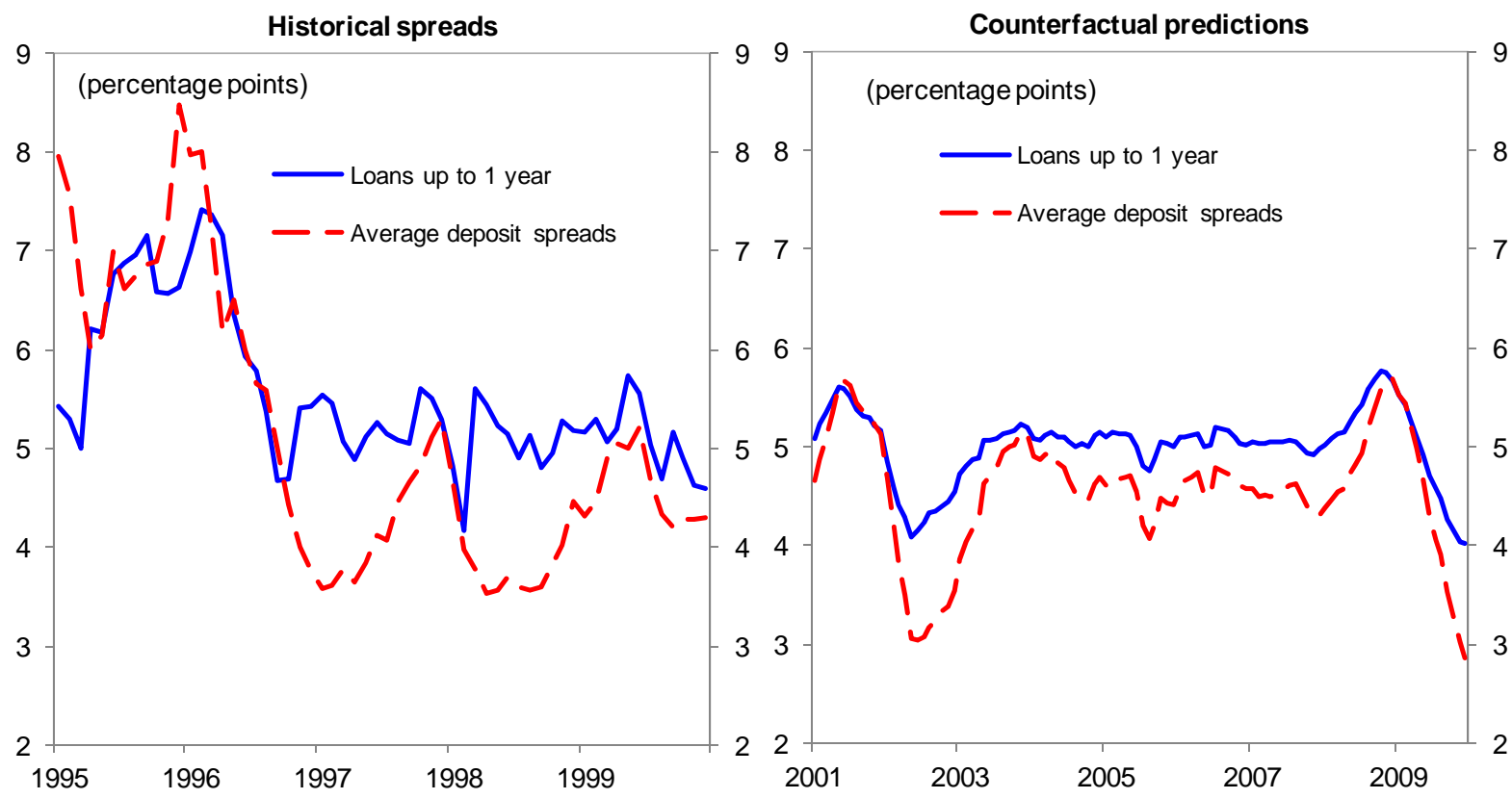

Source: Author's calculations.

Figure 3. Net Savings from Lower Interest Rates Under Dollarization
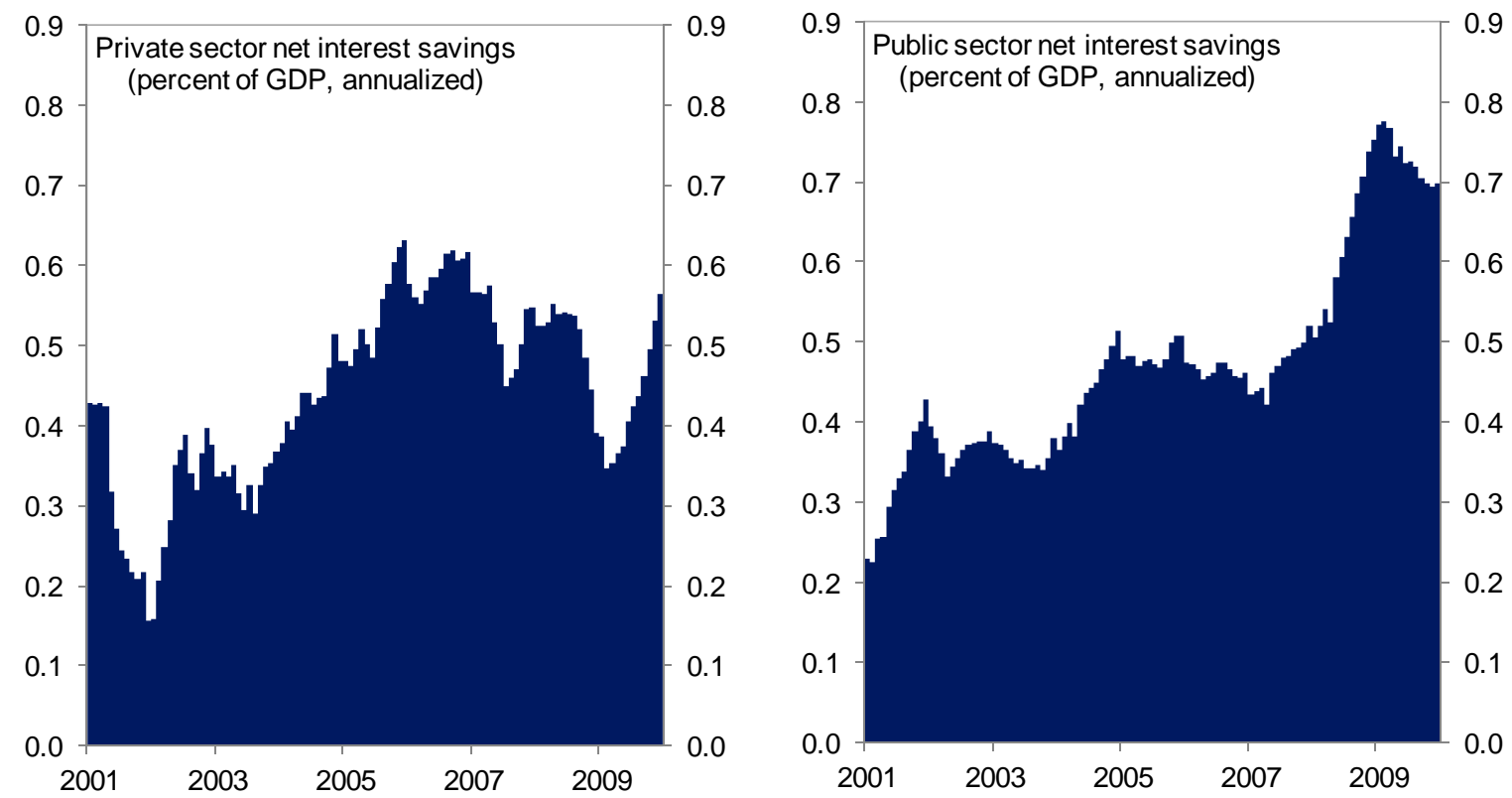

Source: Author's calculations. 


\section{Magnitude of Foregone Seigniorage}

Seigniorage revenue typically represents a gain to the central bank through its issuance of domestic currency as a non-interest-bearing liability. ${ }^{8}$ In nominal terms it is simply equal to the increase in the stock of domestic currency in circulation (see Berg and Borensztein, 2000). Estimating potential seigniorage revenue under dollarization presents a challenge, in that data on the stock of dollars in circulation in the domestic economy is not available. One approach is to assume that, given that economic performance has been similar to that under the peg, when seigniorage revenue averaged $1 / 4$ percent of GDP per year, growth in currency holdings and thus potential seigniorage revenue would also have been similar. Another approach is to assume that the ratio of currency in circulation to other monetary aggregates, such as deposits or bank liquidity reserves, would have remained stable over time. The average over a range of such aggregates also yields estimated seigniorage of $1 / 4$ percent of GDP per year. This serves as a reasonable upper bound for seigniorage under dollarization, given similar rates of inflation and economic growth. ${ }^{9}$

In terms of annual flows, the public sector's gains from lower interest rates outweigh the estimated foregone seigniorage revenue by $1 / 4$ percent of GDP per year (Figure 4). ${ }^{10}$ However, the losses from foregone seigniorage revenue are not strictly comparable to the gains from lower interest rates, as seigniorage represents a transfer of resources from the private sector to the public sector and is not a source of creation of wealth for the economy as a whole.

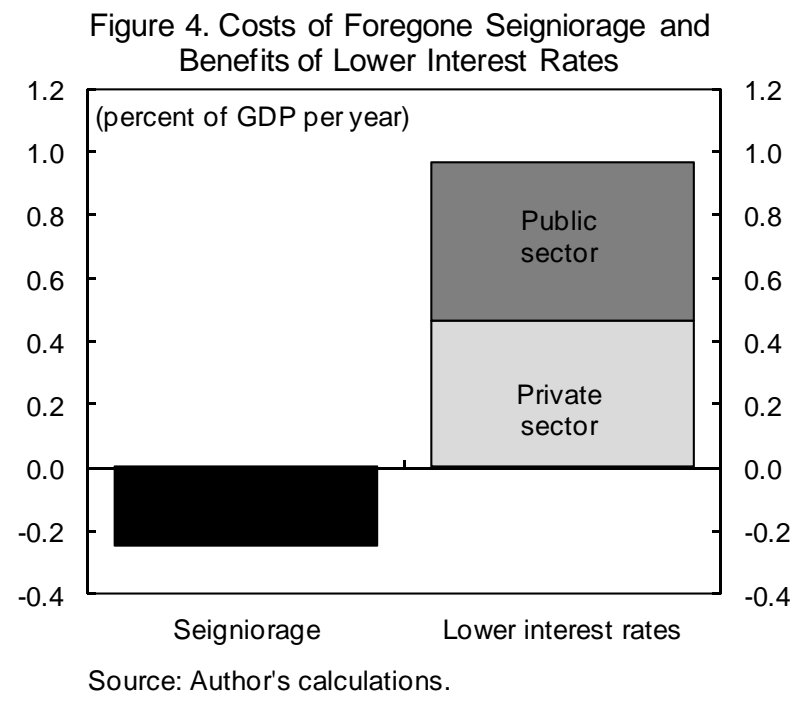

\footnotetext{
${ }^{8}$ Hinds (1999) notes that seigniorage gains are reduced to the extent that the monetary authority pays interest on reserve requirements in domestic currency at a rate higher than the one at which international reserves are remunerated. However, the degree to which required reserves are remunerated can be seen as an independent policy decision (Berg and Borensztein 2000).

${ }^{9}$ Innovations in the means of payment, such as the use of debit and credit cards for transactions, would tend to reduce potential seigniorage. Financial deepening in terms of wider access to bank accounts would also reduce the demand for currency relative to other monetary aggregates.

${ }^{10}$ The central bank also incurs a one-time outlay in retiring the stock of domestic currency existing when the dollar is adopted (Berg and Borensztein, 2000), which for El Salvador was US\$449 million, but this does not represent a recurring cost.
} 


\section{Dollarization AND CyCliCAl STABILIZATION}

This section examines the extent to which the monetary policy prevailing for El Salvador has contributed to the stabilization of inflation and economic activity over the business cycle. If real shocks vary across countries, real exchange rate adjustment could facilitate output stabilization, but this option is renounced under either a fixed exchange rate or official dollarization, with the degree of stabilization depending entirely on the anchor country's monetary policy.

The rationale is that the cycle of the domestic economy is aligned closely enough with that of the anchor economy such that the same monetary policy is optimal for both, in line with the optimum currency area theory (Mundell, 1961; Frankel and Rose, 1998). Some analysts have pointed to this source of potential volatility in real output as one substantial cost of dollarization (Edwards and Magendzo, 2006; Berg and Borensztein, 2000). However, the costs depend in practice on the degree to which monetary policy in the anchor country is appropriate for the business cycle of the country pegging to it.

Standard Taylor rule analysis can shed light on how well the monetary policy of the United States has contributed to output and price stabilization in El Salvador. Taylor (1993) related the optimal monetary policy setting in the context of a target interest rate $i$ to the rate of inflation $\pi$ and the level of output $q$ relative to their equilibrium settings (represented by asterisks in equation (4)):

$$
t-t^{*}=\theta_{\pi}\left(\pi-\pi^{*}\right)+\theta_{q}\left(q-q^{*}\right)
$$

where $\theta_{\pi}$ and $\theta_{q}$ are coefficients measuring the strength of the monetary policy response to inflation and output, respectively. A vast subsequent literature has presented alternatives to Taylor's original formulation (see Orphanides, 2007, for references). ${ }^{11}$ Given the inherent difficulties in measuring the level of potential output in El Salvador due to its sizable informal sector and limited labor market data, this paper uses output growth as the preferred measure of productive capacity. ${ }^{12}$ Including the lagged policy rate and allowing for a nonzero constant (representing the equilibrium real interest rate) and an error term, the estimated policy rule can be expressed as:

\footnotetext{
${ }^{11}$ The rule in its original form is stated in terms of current inflation and output, although the unemployment rate or output growth are often used as measures of the economy's potential productive capacity. Given the lags inherent in the transmission of monetary policy to the real economy, these rules have often been estimated using forecasts of the independent variables (see Siklos and Bohl, 2009, for a recent example). Also, a lagged interest rate term is often included to account for inertial behavior in setting interest rates, which can be important when expectational channels are strong (Orphanides, 2003).

${ }^{12}$ The results did not change when using potential output estimated with an HP filter.
} 


$$
t_{\mathrm{t}}=\alpha+\theta_{t} t_{\mathrm{t}-1}+\theta_{\pi} \pi_{\mathrm{t}}+\theta_{q} \phi_{\mathrm{t}}+\varepsilon_{\mathrm{t}}
$$

where the fourth term is the four-quarter percent change in real GDP. The magnitudes of $\theta_{\pi}$ and $\theta_{q}$ in equation (5) yield a measure of the weight placed by policymakers on the stabilization of prices and output, with higher values signifying a stronger response to increases in these variables. Accounting for the influence of the lagged dependent variable, the long-run responses of monetary policy to the two variables are equal to $\frac{\theta_{\pi}}{\left(1-\theta_{i}\right)}$ for inflation

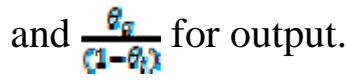

\section{A. Costs and Benefits for El Salvador}

Equation (5) was estimated for the U.S. Federal Funds rate vis-à-vis El Salvador under both the peg and official dollarization, and Figure 5 displays the long-run coefficients. While the domestic short-term lending rate (measured by the rate at the central bank's overnight liquidity window) under the peg was focused on the exchange rate objective, it did not move one-for-one with the U.S. Federal Funds rate, so to evaluate whether these deviations were helped to stabilize growth or inflation the estimated coefficients from a rule including it are also presented. In the base specification, using headline inflation (upper-left panel), U.S. Federal Reserve policy during the peg was acyclical with respect to Salvadoran inflation and mildly countercyclical with respect to activity, indicating that it made a modest contribution to stabilizing domestic output, while the domestic short-term lending rate tended to tighten in times of higher inflation but ease when output growth was rising. Given the empirical drivers of the currency risk premium established in Section II, these responses are consistent with the primacy of the exchange rate objective. Under official dollarization, the U.S. Federal Funds rate has been mildly procyclical with respect to inflation but highly countercyclical with respect to Salvadoran growth. The results are similar using core inflation (upper-right panel), except that under dollarization the Federal Funds rate has helped to stabilize both inflation and output.

One potential critique of these findings is that they assume the monetary authority sets policy relative to current inflation and output growth instead of in a forward-looking manner. To evaluate this critique, equation (5) was re-estimated for each regime using the actual values of inflation and output growth four quarters into the future, in the absence of data on expectations of Salvadoran growth and inflation. ${ }^{13}$ These results (lower panels of Figure 5) show that increases in Salvadoran activity have generally been preceded by Federal Reserve tightening, much more so than either the U.S. Federal Funds rate or the domestic short-term

\footnotetext{
${ }^{13}$ These results rely crucially on an absence of systematic bias in inflation and output forecasts by policymakers. However, the presence of any systematic bias in the forecasts of policymakers would in itself argue for less independence in monetary policy.
} 
Figure 5. Monetary Policy Response to Inflation and Output

(Long-run change in monetary policy rate associated with one percentage point increase in output growth and inflation)
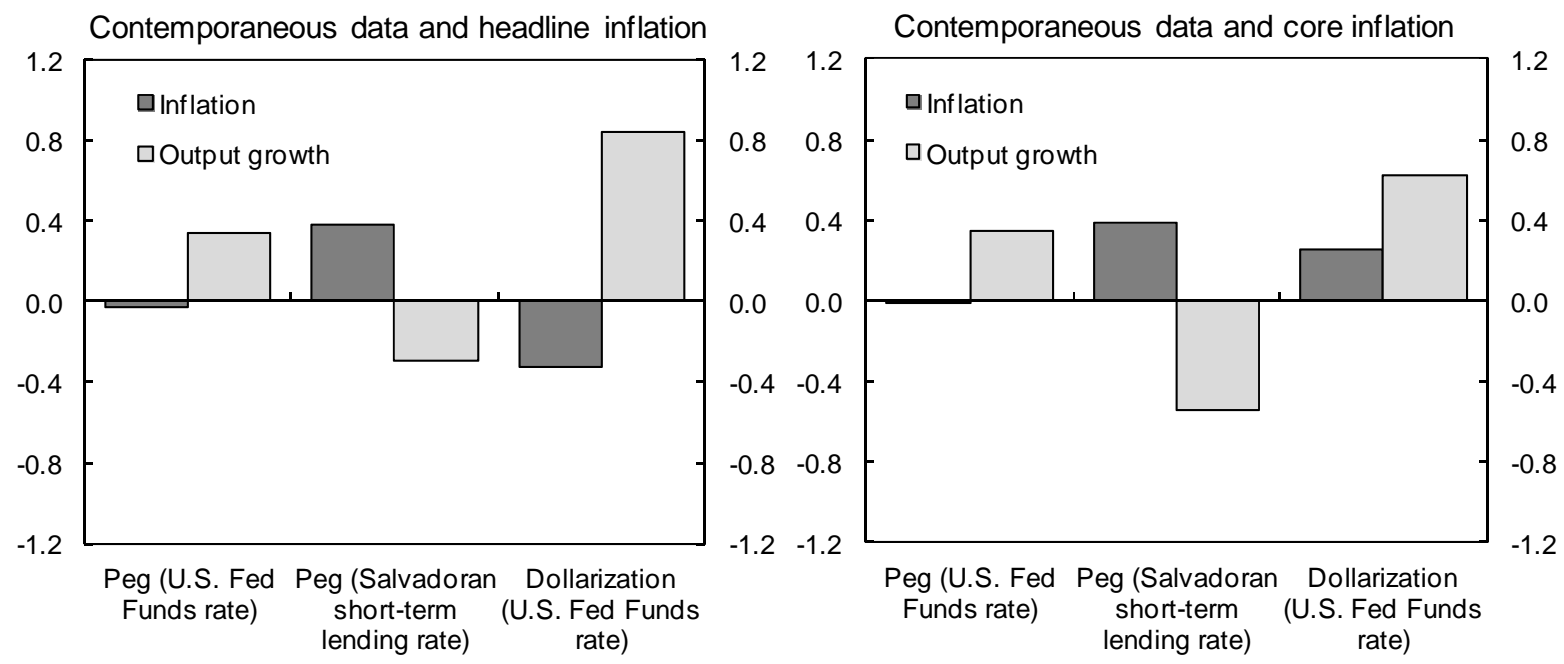

Four-quarter ahead data and headline inflation

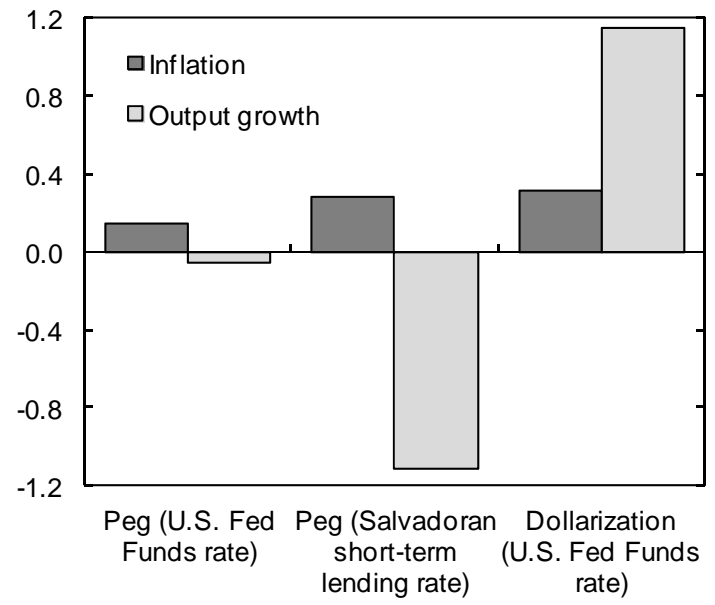

Four-quarter ahead data and core inflation

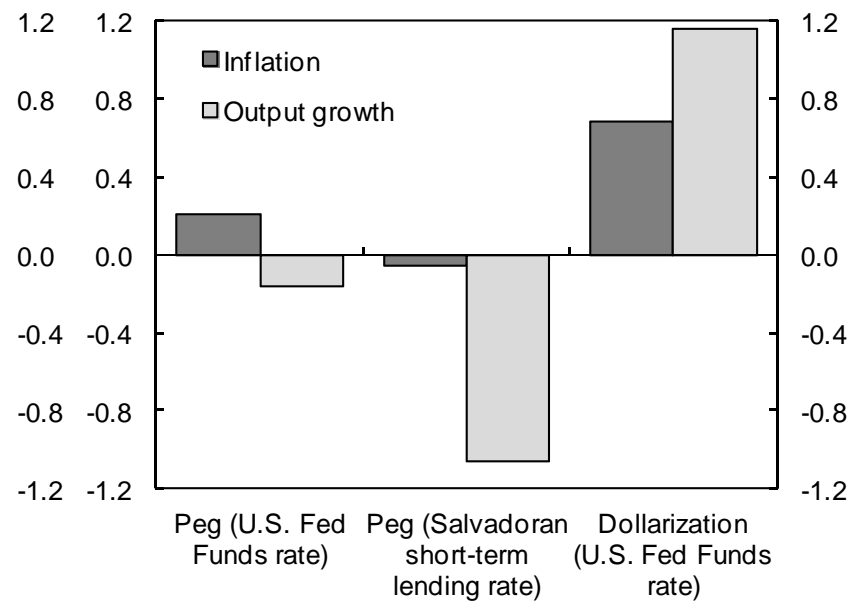

Source: Author's calculations.

lending rate under the peg (where the estimated relationship is strongly negative). Since dollarization, Federal Reserve policy has also tended to tighten in advance of inflationespecially core-more than it or the domestic short-term lending rate did under the peg. Given the lags with which monetary policy tends to affect output and prices, these findings suggest that compared to the peg, the monetary policy prevailing under official dollarization has not been detrimental to the stabilization of El Salvador's business cycle.

Thus, while Federal Reserve policy is set in accord with economic conditions in the United States and not El Salvador, with respect to El Salvador it has been more countercyclical since dollarization than it or the domestic short-term lending rate were under the peg. While El Salvador was anchored to U.S. monetary policy under both regimes, the 
enhanced cyclical stabilization follows directly from the closer synchronization of business cycles under dollarization, as the correlation of year-on-year output growth has risen to 0.7 from minus 0.3 under the peg, and the correlation of year-on-year inflation has risen to 0.8 from 0.3. El Salvador's higher real and financial integration with the United States since dollarization has been in line with the rest of the region's over that period (see Swiston, 2010) while the increase in its correlation with the U.S. cycle has surpassed that of the rest of the region, suggesting that at least some of this synchronization could stem from the effects of official dollarization itself, in line with the argument of Frankel and Rose (1998) that there is a degree of endogeneity in the criteria for optimum currency areas.

\section{B. Cross-Country Comparisons}

The close synchronization of Salvadoran activity with that in the United States has mitigated the costs associated with the lack of independent monetary policy under official dollarization. In fact, El Salvador appears to have benefitted from greater cyclical stabilization under dollarization than either Ecuador or Panama, where U.S. monetary policy has not been so strongly associated with either inflation or output growth (Figure 6) ${ }^{14}$ This is consistent with the lower correlation of growth in these countries with U.S. growth-0.3 for Ecuador and 0.5 for Panama, versus 0.7 for El Salvador.

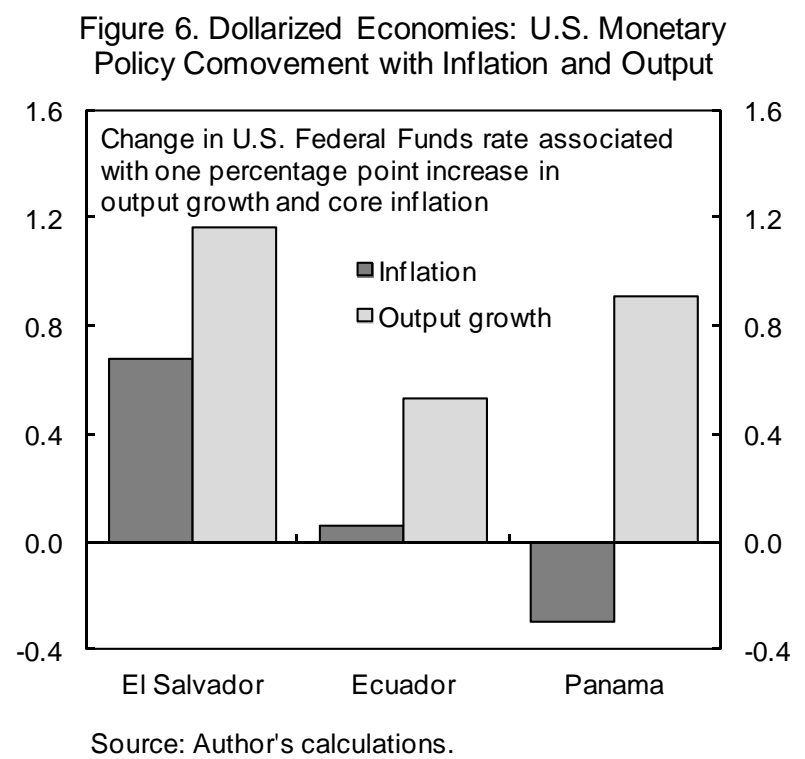

The experience of Central American countries with floating exchange rates could shed light on whether an independent monetary policy would significantly outperform full dollarization in stabilizing Salvadoran inflation or output growth. Costa Rica, the Dominican Republic, and Guatemala operate under floating or managed floating exchange rates and, to varying degrees, have recently exercised independent monetary policies. ${ }^{15}$ While information on monetary policy rates is only available for these countries since 2005, Taylor rule estimates for these countries provide an indication of the ability of the monetary authorities to exercise countercyclical policy during an expansion (2005-07) and a slowdown (2008-09).

\footnotetext{
${ }^{14}$ Using four-quarter-ahead core inflation and output growth. El Salvador's coefficients are also higher than Ecuador's and Panama's in the other specifications.

${ }^{15}$ The IMF's Annual Report on Exchange Arrangements and Exchange Restrictions classifies Costa Rica and the Dominican Republic as "Other Managed Arrangement" and Guatemala as "Floating." Honduras is classified as "Stabilized Arrangement" and Nicaragua as "Crawling Peg."
} 
Figure 7 shows that policy in all three countries has responded moderately to core inflation, with a response coefficient averaging $0.4 .^{16}$ The long-run response of policy to output growth has also averaged about 0.4 . While the short sample period means that any conclusions drawn from these estimates are tentative in nature, they suggest that an independent monetary policy can help stabilize inflation and output, but gains relative to El Salvador's experience under dollarization do not appear to be substantial. In sum, this analysis has not yielded any evidence indicating that moving to a more flexible exchange rate in El Salvador would yield sizeable improvements in terms of cyclical stabilization.

Figure 7. Central America: Monetary Policy Response to Inflation and Output

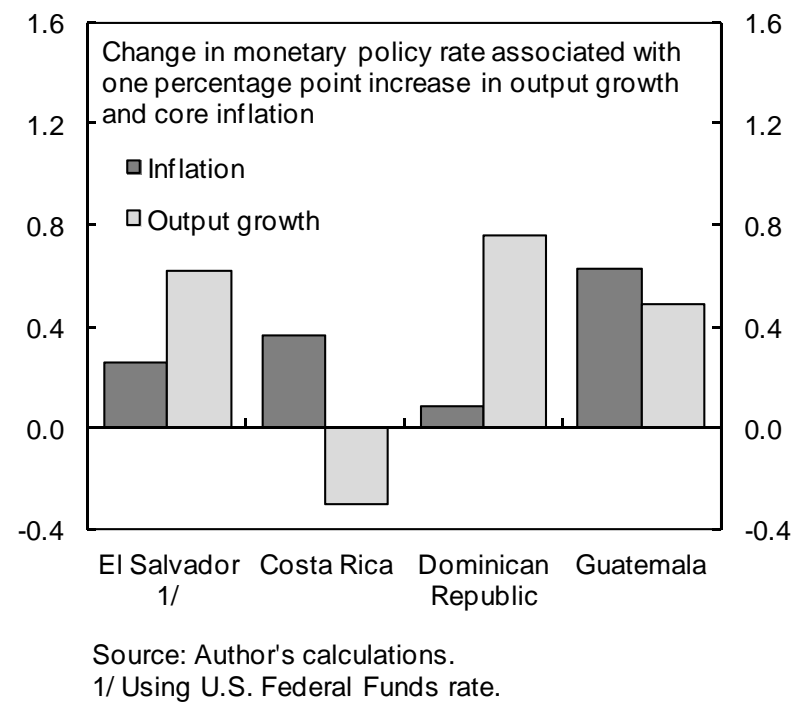

\section{Dollarization ANd Monetary Policy Transmission}

It is crucial to examine the transmission of monetary policy in order to evaluate the benefits and costs of dollarization. Federal Reserve policy may have had some desirable countercyclical properties for El Salvador since dollarization, but if policy rates failed to influence actual lending and deposit rates, these benefits would be negated. In this light, this section analyzes pass-through of interest rates in El Salvador both prior to and since dollarization, as well as in other relevant comparators.

Pass-through is measured using an autoregressive distributed lag (ADL) specification that is common in the literature (see, for example, Espinosa and Rebucci, 2003, and de Bondt, 2002). The standard ADL model with one lag is written as:

$r r_{t}=\alpha_{0}+\alpha_{1} r r_{t-1}+\alpha_{2} m p r_{t}+\alpha_{3} m p r_{t-1}+\varepsilon_{t}$

where $r r$ is the retail lending or deposit rate and $m p r$ is the monetary policy rate. Given the frequency with which interest rates are non-stationary, all the series under analysis were first tested for unit roots. In cases for which unit roots were found in both the retail rate and the monetary policy rate, tests were conducted for the presence of cointegration (results available

\footnotetext{
${ }^{16}$ The source for all countries is the Central American Monetary Council. The specification with contemporaneous data is used because of the short sample, while rules estimated using headline inflation yielded similar results.
} 
from the author), which would allow the ADL model in (6) to be re-parameterized as in Hendry and Nielsen (2007, p. 215):

$$
\Delta r r_{\mathrm{t}}=\alpha_{2} \Delta m p r_{\mathrm{t}}+\beta_{1}\left(r r_{\mathrm{t}-1}-\beta_{0}-\beta_{2} m p r_{\mathrm{t}-1}\right)+\mu_{\mathrm{t}}
$$

where $\beta_{1}$ represents the speed of adjustment from the short-term impact $\alpha_{2}$ to the long-run impact $\beta_{2}$. Complete pass-through would imply a value for $\beta_{2}$ of one. In those groups of data for which unit roots or cointegration were not found, the above specification could yield spurious coefficients, and the equation was specified purely in differences:

$$
\Delta r r_{t}=a_{1}+\alpha_{2} \Delta m p r_{t}+a_{3} \Delta m p r_{t-1}+a_{4} \Delta r r_{t-1}+\mu_{t}
$$

In this case, long-run pass-through is given by $\left(\alpha_{2}+\alpha_{3}\right) /\left(1-\alpha_{4}\right)$.

\section{A. Pass-through in El Salvador}

Table 3 shows the estimated long-run coefficients under both the fixed exchange rate regime and official dollarization for loans of up to one year and three different maturities of time deposits. Under the peg, pass-through of the Federal Funds rate to dollar-denominated rates in El Salvador was never significantly different from zero. Commercial bank interest rates in colones were driven by the domestic short-term lending rate in colones (the Federal Funds rate was not significant), with statistically significant pass-through in all cases. Pass-through under dollarization is also statistically significant except for lending rates, although in that case the magnitude of pass-through is in the same range as the other estimates. The differences in coefficients across monetary regimes is not statistically significant. The average long-run impact of a 100 basis points change in the monetary policy rate has typically generated a movement of 50 to 90 basis points in the rates prevailing at commercial banks, the same as under the peg.

\begin{tabular}{|c|c|c|c|c|c|}
\hline & \multirow[t]{2}{*}{ Loans } & \multicolumn{4}{|c|}{ Deposits } \\
\hline & & 30-day & 90-day & 180-day & Average \\
\hline In Dollars, 1995 to 1999 & $\begin{array}{r}0.279 \\
(0.349)\end{array}$ & $\begin{array}{r}-0.168 \\
(0.415)\end{array}$ & $\begin{array}{r}-0.117 \\
(0.507)\end{array}$ & $\begin{array}{r}0.169 \\
(0.596)\end{array}$ & -0.039 \\
\hline In Colones, 1995 to 1999 & $\begin{array}{l}0.892 \text { *** } \\
(0.211)\end{array}$ & $\begin{array}{l}0.717 \text { *** } \\
(0.202)\end{array}$ & $\begin{array}{l}0.502 \text { ** } \\
(0.213)\end{array}$ & $\begin{array}{l}0.580 \text { *** } \\
(0.163)\end{array}$ & 0.599 \\
\hline In Dollars, 2001 to 2010 & $\begin{array}{r}0.502 \\
(0.308)\end{array}$ & $\begin{array}{l}0.855 \text { ** } \\
(0.361)\end{array}$ & $\begin{array}{l}0.696 \text { ** } \\
(0.283)\end{array}$ & $\begin{array}{l}0.568 \text { *** } \\
(0.179)\end{array}$ & 0.706 \\
\hline
\end{tabular}

Table 3. Pass-Through of Monetary Policy Rate to Commercial Bank Rates

Source: Author's calculations.

Notes: Heteroskedasticity and autocorrelation-adjusted standard errors are in parentheses, while *, **, and *** represent coefficients that are significant at the 10,5 , or 1 percent levels. Constant term not shown.

Linkages between U.S. monetary policy and Salvadoran interest rates have become tighter under official dollarization, allowing El Salvador to take better advantage of the 
countercyclical properties of U.S. monetary policy with respect to the Salvadoran business cycle. Meanwhile, the magnitude of pass-through from monetary policy rates to commercial bank interest rates has not been substantially different, suggesting that the monetary regime has not affected the power of the monetary transmission mechanism in El Salvador.

\section{B. Cross-Country Comparisons}

Figure 8 presents pass-through estimates for El Salvador under dollarization, for Ecuador and Panama for the same period, and estimates for the United States as benchmarks. ${ }^{17}$ The lending rates used are for commercial bank loans up to one year except for the United States, where the average pass-through for the prime lending rate and 6-month LIBOR were used. ${ }^{18}$ The coefficients for deposits are an average of those estimated for 30day, 90-day, and 180-day time deposits. Long-run pass-through to lending rates in El Salvador exceeds the low levels seen in Ecuador and Panama, while falling short of the nearly complete pass-through in the United States. ${ }^{19}$ Pass-through to deposit rates in El Salvador is below that of the United States, but higher than that in Ecuador and on par with that in Panama.

Figure 8. Interest Rate Pass-Through in Economies Using the U.S. Dollar

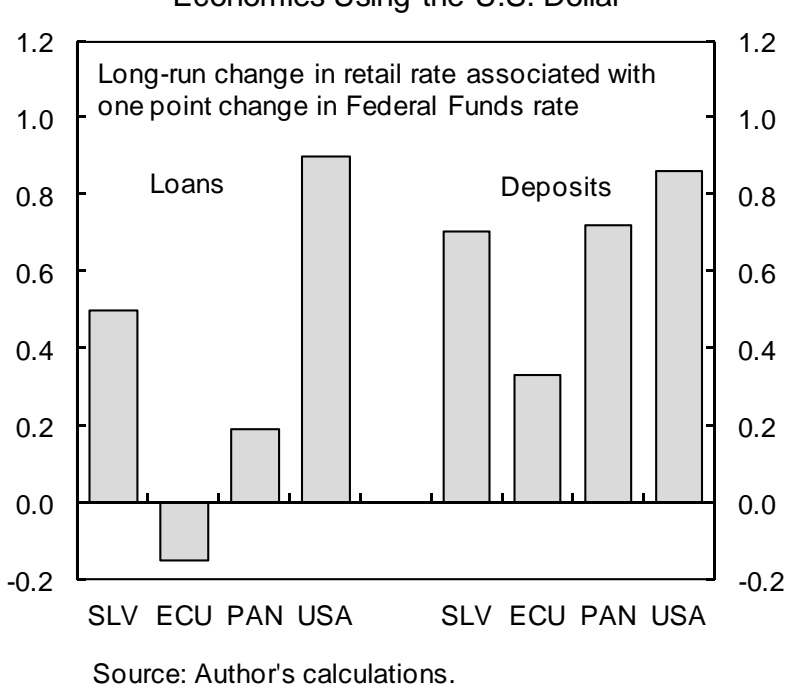
Overall, the degree of pass-through under dollarization compares favorably with other dollar-using economies.

Instruments denominated in dollars are available in all Central American countries, allowing a comparison of the transmission of the U.S. Federal Funds rate to commercial bank interest rates throughout the region. Figure 9 compares pass-through from the U.S. Federal Funds rate to dollar rates on loans up to one year and 180-day deposits in El Salvador with the median of estimates at the same maturity for Costa Rica, the Dominican Republic, Guatemala, Honduras, and Nicaragua, starting in 2001 for all countries. The degree of pass-

\footnotetext{
${ }^{17}$ Data for Ecuador only extend through 2007.

18 The former is a rate at which banks are willing to lend to their highest-quality customers and the base for a number of other variable-rate loans, but does not strictly represent a measurement of rates on actual loans, while the latter is a rate charged by banks on their operations with other banks. These two rates are frequently used in analysis of pass-through in the United States.

19 These estimates are consistent with other studies' estimates of U.S. pass-through (see Espinosa-Vega and Rebucci, 2003).
} 
through to both lending and deposit rates in dollars is equal to or greater than elsewhere in Central America.

Figure 9. Central America: Pass-Through to U.S. Dollar Interest Rates

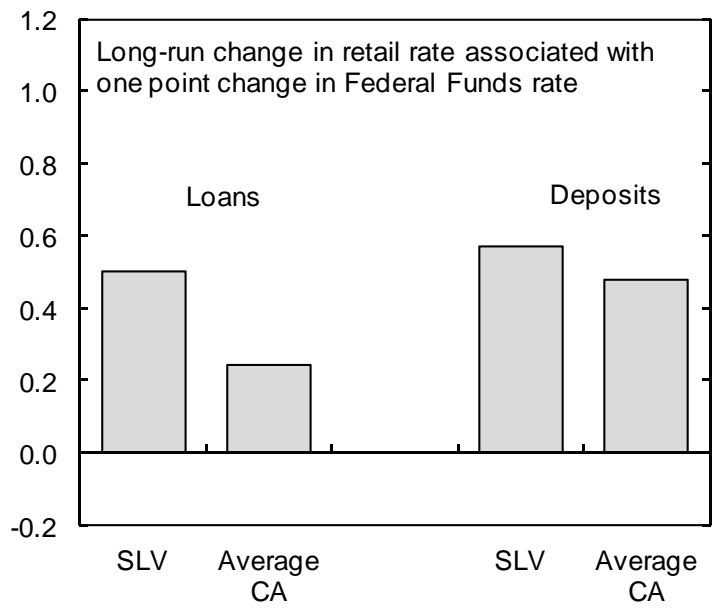

Source: Author's calculations.
Figure 10. Central America: Pass-Through to Domestic Currency Interest Rates

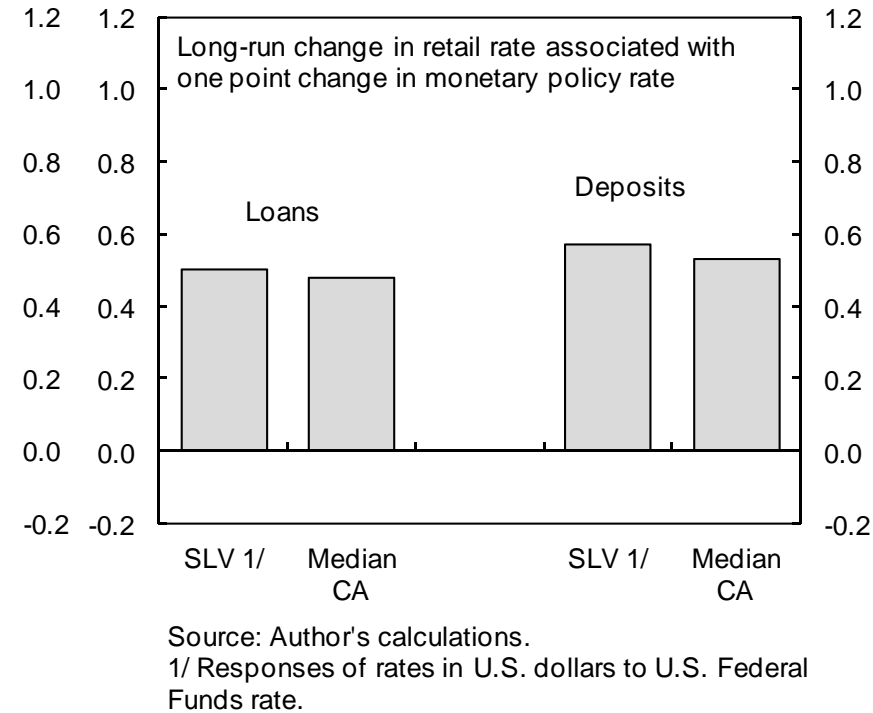

To evaluate the potential benefits of a monetary regime with a separate domestic currency and an independent monetary policy, pass-through to Salvadoran rates in dollars can be compared to pass-through from domestic monetary policy rates to commercial bank rates in domestic currency in the rest of the region. Figure 10 compares estimates for the same countries at the same maturities as in Figure 9. The long-run responses in El Salvador are almost the same as those in the rest of the region and are in line with independent estimates contained in Medina Cas and others (2011). The sample is very short for drawing firm conclusions because data on domestic monetary policy rates in Central America is only available starting in 2005, but given the available evidence there do not appear to be substantial differences between the pass-through of the U.S. Federal Funds rate to Salvadoran rates in dollars and that of domestic monetary policy rates to rates on instruments in domestic currency in the rest of Central America.

Overall, there is little evidence that official dollarization limits the extent of pass-through to commercial bank interest rates in El Salvador. Pass-through of the U.S. Federal Funds rate has been higher under dollarization than under the peg, and has been as about high as that experienced under the peg on interest rates on instruments in colones. It has met or exceeded pass-through in Ecuador and Panama, with the latter finding especially striking given Panama's open and competitive financial system, and has been greater in El Salvador than for U.S. dollar interest rates in other Central American countries. Finally, pass-through of U.S. monetary policy to El Salvador has been similar to that of domestic monetary policy rates in Central America to rates on instruments denominated in domestic currency. 


\section{Factors Explaining Pass-Through}

This subsection attempts to shed some light on the degree of pass-through by investigating which factors can help explain gaps between commercial bank interest rates in the United States and El Salvador under official dollarization. Explaining variation in these gaps over time may help to account for the incomplete pass-through of U.S. monetary policy to Salvadoran commercial bank interest rates found in the previous subsection.

Salvadoran rates would be expected to converge with U.S. rates under official dollarization, although, as seen in equation (2) in section II, other factors could drive a wedge between the two rates. ${ }^{20}$ This analysis focuses on factors that could change significantly over the decade in which official dollarization has been in effect. The degree of pass-through could potentially be attributed to various factors, including fiscal sustainability; macroeconomic conditions; or features of the banking system, including capital constraints, the availability of liquidity, or the credit quality of potential borrowers, as in the following equation:

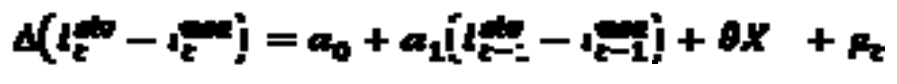

where $X$ is a vector of the variables mentioned above. The second term allows for the reversion of the El Salvador-U.S. interest rate gap to an equilibrium value over time.

Table 4 presents estimation results for equation (9), using real GDP growth as a control for macroeconomic conditions and the EMBI spread as a proxy reflecting markets' views of fiscal sustainability. Given that the EMBI could also reflect the degree of risk aversion in global financial markets, the VIX volatility index, a common measure of risk aversion, is included as an additional control variable. The results indicate that the EMBI spread was a strong driver of the gap between Salvadoran and U.S. interest rates for both loans and deposits, even accounting for global risk aversion. Economic growth and the lagged level of the gap were also significant, especially for lending rates. Conditions in the domestic banking system, especially the capital-asset ratio and the non-performing loan ratio were also significant determinants of interest rates.

Average coefficients across the two types of loans and three maturities of deposits are shown in Figure 11 alongside comparable coefficients for Panama.

- $\quad$ El Salvador’s EMBI spread, a proxy for fiscal sustainability reflecting markets’ views, is a significant driver of pass-through to Salvadoran interest rates. An increase of 100 basis points in this spread raises lending and deposit rates by 35 to 40 basis points, similar to the effects estimated for Panama.

\footnotetext{
${ }^{20}$ While several works have related differences in pass-through across countries to structural features of the banking system (Cottarelli and Kourelis, 1994; Mojon, 2000), analysis of changes in pass-through over time within one country has been less common.
} 
Table 4. Factors Affecting the El Salvador-U.S. Interest Rate Gap

\begin{tabular}{|c|c|c|c|c|c|}
\hline \multicolumn{6}{|c|}{ Dependent variable: change in the EI Salvador-U.S. interest rate gap for a given instrument } \\
\hline & \multicolumn{2}{|c|}{ Loans } & \multicolumn{3}{|c|}{ Deposits } \\
\hline & Prime rate & Six-month LIBOR & 30-day & 90-day & 180-day \\
\hline $\begin{array}{l}\text { Real GDP growth } \\
\text { (four-quarter percent change) }\end{array}$ & $\begin{array}{l}-0.23 * * \\
(0.09)\end{array}$ & $\begin{array}{l}-0.31 * * \\
(0.11)\end{array}$ & $\begin{array}{l}-0.18 \\
(0.11)\end{array}$ & $\begin{array}{l}-0.25 * * \\
(0.11)\end{array}$ & $\begin{array}{l}-0.19 * \\
(0.10)\end{array}$ \\
\hline $\begin{array}{l}\text { EMBI spread } \\
\text { (lagged change) }\end{array}$ & $\begin{array}{l}0.39 * * \star \\
(0.05)\end{array}$ & $\begin{array}{l}0.33^{* \star \star} \\
(0.04)\end{array}$ & $\begin{array}{l}0.544^{\star \star \star} \\
(0.04)\end{array}$ & $\begin{array}{l}0.44^{\star * \star} \\
(0.04)\end{array}$ & $\begin{array}{l}0.28^{* \star \star} \\
(0.04)\end{array}$ \\
\hline $\begin{array}{r}\text { Capital-asset ratio } \\
\text { (lagged change) }\end{array}$ & $\begin{array}{l}-0.88 * * \\
(0.31)\end{array}$ & $\begin{array}{l}-0.88 * \\
(0.46)\end{array}$ & $\begin{array}{l}-0.83^{\star *} \\
(0.35)\end{array}$ & $\begin{array}{l}-0.82 * * \\
(0.35)\end{array}$ & $\begin{array}{l}-0.73 \text { ** } \\
(0.32)\end{array}$ \\
\hline $\begin{array}{l}\text { Liquid asset ratio } \\
\text { (lagged change) }\end{array}$ & $\begin{array}{r}-0.05 \\
(0.07)\end{array}$ & $\begin{array}{r}-0.05 \\
(0.09)\end{array}$ & $\begin{array}{r}-0.05 \\
(0.06)\end{array}$ & $\begin{array}{r}-0.04 \\
(0.06)\end{array}$ & $\begin{array}{r}-0.05 \\
(0.05)\end{array}$ \\
\hline $\begin{array}{l}\text { Non-performing loans } \\
\text { (change, in percent of total loans) }\end{array}$ & $\begin{array}{l}0.86 * \star \\
(0.32)\end{array}$ & $\begin{array}{l}1.04^{\star * \star} \\
(0.33)\end{array}$ & $\begin{array}{l}0.70 * \\
(0.37)\end{array}$ & $\begin{array}{l}0.75 * \\
(0.42)\end{array}$ & $\begin{array}{r}0.57 \\
(0.39)\end{array}$ \\
\hline $\begin{array}{l}\text { VIX volatility index } \\
\text { (percent change) }\end{array}$ & $\begin{array}{l}0.05^{* \star \star} \\
(0.01)\end{array}$ & $\begin{array}{l}0.04^{\star \star \star} \\
(0.00)\end{array}$ & $\begin{array}{l}0.03^{* \star \star} \\
(0.01)\end{array}$ & $\begin{array}{l}0.02 * * \star \\
(0.00)\end{array}$ & $\begin{array}{l}0.011^{\star \star \star} \\
(0.00)\end{array}$ \\
\hline $\begin{array}{l}\text { Interest rate gap } \\
\text { (lagged level) }\end{array}$ & $\begin{array}{l}-0.23 * * \\
(0.09)\end{array}$ & $\begin{array}{l}-0.33 * * \\
(0.15)\end{array}$ & $\begin{array}{r}-0.27 \\
(0.19)\end{array}$ & $\begin{array}{l}-0.39 \text { * } \\
(0.22)\end{array}$ & $\begin{array}{r}-0.29 \\
(0.19)\end{array}$ \\
\hline Adjusted R-squared & 0.64 & 0.58 & 0.78 & 0.69 & 0.58 \\
\hline Durbin-Watson stat & 2.05 & 1.81 & 1.68 & 1.83 & 1.92 \\
\hline
\end{tabular}

Source: Author's calculations.

Notes: Sample period is Q4-2003 through 2010-Q1. Heteroskedasticity and autocorrelation-adjusted standard errors are in parentheses, while *, ${ }^{* *}$, and ${ }^{* *}$ represent coefficients that are significant at the 10,5 , or 1 percent levels. Constant and $\operatorname{ar}(1)$ terms not shown.

- $\quad$ An increase of one percentage point in the ratio of banks' capital to assets on their balance sheets (lagged to minimize simultaneity issues) reduces Salvadoran lending rates by 90 basis points and deposit rates by 80 basis points, suggesting that when banks are holding an abundance of capital they ease lending terms and reduce the price they pay for funding. Bank capital was not found to be a statistically significant determinant of rates in Panama, although it had the correct sign.
Figure 11. El Salvador and Panama: Factors Affecting the Interest Rate Gap

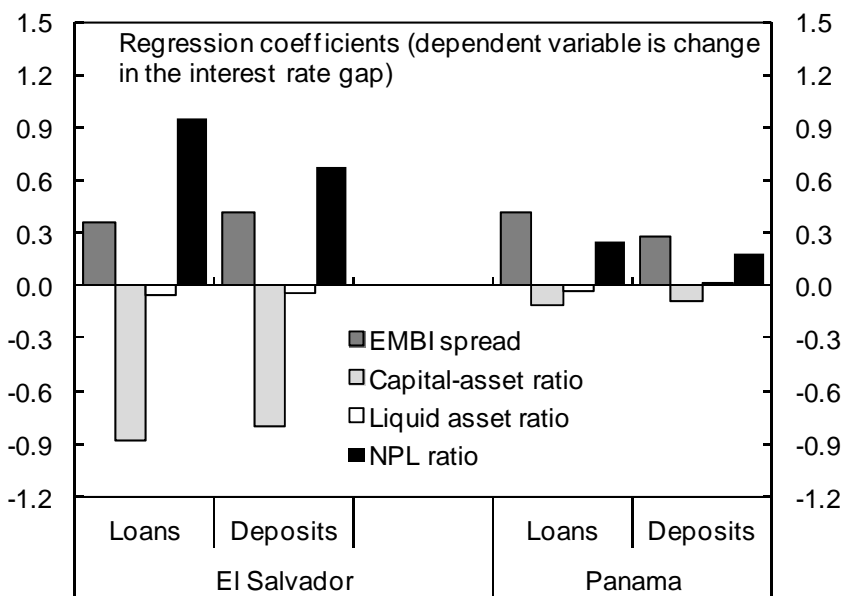

Source: Author's calculations.

- An increase of one percentage point in the ratio of non-performing loans to total loans raises the gap on Salvadoran lending rates by 95 basis points and that on deposit rates by 70 basis points, suggesting that a deterioration in the credit quality of their portfolios causes banks to both re-evaluate the risk characteristics of new borrowers 
and attempt to attract funding. This variable was not significant for Panama, although the it had the correct sign.

- $\quad$ Liquidity holdings of commercial banks (also lagged) are not found to significantly affect changes in interest rates vis-à-vis the United States in either El Salvador or Panama.

The transmission of U.S. interest rates to El Salvador depends heavily on conditions in the banking system and market views of fiscal sustainability, as these factors explain between over half of the variation in the El Salvador-U.S. interest rate gap. These results suggest that progress on fiscal consolidation and maintaining sound risk management in the banking system are crucial elements in allowing El Salvador to fully enjoy the potential benefits of low interest rates and quick transmission of U.S. monetary policy to the domestic economy offered by official dollarization.

\section{Conclusions}

This paper has examined the effects of El Salvador's transition to official dollarization from a peg to the U.S. dollar and compared relevant aspects of its performance to other officially dollarized countries and regional peers.

Dollarization has been associated with a large reduction in the currency risk premium implicit in Salvadoran interest rates, generating substantial savings for the economy. Estimates of the currency risk premium in a real interest parity framework indicate that interest rates under the peg were driven by fluctuations in real activity, credit growth, growth of net international reserves, and inflation. A counterfactual simulation suggests that the lending and deposit rates prevailing at commercial banks in El Salvador under official dollarization have been 4 to 5 percentage points lower than they would have been if the peg had remained in effect. This implies net interest savings of $1 / 2$ percent of GDP per year for the Salvadoran private sector and $1 / 4$ percent of GDP for the public sector, taking into account the opportunity cost of foregone seigniorage under dollarization.

U.S. monetary policy has contributed to the cyclical stability of inflation and output in El Salvador to a greater degree under official dollarization than it did under the peg. This is likely a result of El Salvador's tight integration with the U.S. economy and the high correlation between the two countries' business cycles. Taylor rules estimated for the two regimes find that U.S. Federal Reserve policy under official dollarization has tended to stabilize fluctuations in Salvadoran prices and has been highly countercyclical with respect to Salvadoran economic activity, thus helping to mitigate output fluctuations. The experience of Central American countries with floating exchange rates does not suggest that an independent monetary policy would bring El Salvador significant gains in this area.

Pass-through of U.S. monetary policy to Salvadoran commercial bank interest rates has been significantly stronger under official dollarization than it was under the peg. Rates have been 
just as responsive to the Federal Funds rate as they were to the domestic overnight lending rate under the peg. Pass-through is on par with that in Panama, which has a highly open and competitive banking system. Domestic interest rates are just as sensitive to Federal Reserve policy as the rates in other Central American countries are to their own monetary policy rates. A high proportion of the remaining gap between Salvadoran and U.S. commercial bank interest rates is explained by market views of fiscal sustainability and the financial soundness of the banking system, implying that the benefits of dollarization could be maximized by engaging in fiscal consolidation and further bolstering bank supervision and regulation. These results underscore the importance of sustainable fiscal policy and sound financial supervision in an officially dollarized economy.

This paper leaves unexplained some facets of El Salvador's macroeconomic performance that would require a broader cross-country analysis, namely growth in economic activity and international trade, and the effects of dollarization on international financial integration. Progress in these areas is left for future research. 


\section{References}

Aizenman, J., K. Kletzer, and B. Pinto, 2005, “Sargent-Wallace Meets Krugman-FloodGarber, or: Why Sovereign Debt Swaps do not Avert Macroeconomic Crises,” The Economic Journal, Vol. 115, No. 2, pp. 343-367.

Ball, L., 2010, “The Performance of Alternative Monetary Regimes,” NBER Working Paper No. 16124 (Cambridge, MA: National Bureau of Economic Research).

Berg, A., and E. Borensztein, 2000, “The Pros and Cons of Full Dollarization,” IMF Working Paper 00/50 (Washington: International Monetary Fund). Available on the internet at: http://www.imf.org/external/pubs/ft/wp/2000/wp0050.pdf

Cottarelli, C., and A. Kourelis, 1994, "Financial Structure, Bank Lending Rates, and the Transmission Mechanism of Monetary Policy,” IMF Staff Papers, Vol. 41, No. 4, pp. 587-623.

de Bondt, G., 2002, “Retail Bank Interest Rate Pass-Through: New Evidence at the Euro Area Level,” ECB Working Paper No. 136 (Frankfurt: European Central Bank). Available on the internet at: http://www.ecb.int/pub/pdf/scpwps/ecbwp136.pdf

de García, Y., J. Arévalo, and A. Hernández, 2010, “Fundamentos Económicos del Sistema Monetario en El Salvador,” Central Reserve Bank of El Salvador Occasional Paper 2010/01. Available on the internet at: http://www.bcr.gob.sv/downloads.php?dta=931

Doblas-Madrid, A., 2009, “Fiscal Trends and Self-Fulfilling Crises,” Review of International Economics, Vol. 17, No. 1, pp. 187-204.

The Economist, 2000, “Dollars and Debts,” April 8, Vol. 355, Issue 8165, p. 38.

Edwards, S., and I. Magendzo, 2006, "Strict Dollarization and Economic Performance: An Empirical Investigation” Journal of Money, Credit, and Banking, Vol. 38, No. 1, pp. 269-282.

Espinosa-Vega, M., and A. Rebucci, 2003, “Retail Bank Interest Rate Pass-Through: Is Chile Atypical?” IMF Working Paper 03/112 (Washington: International Monetary Fund). Available on the internet at: http://www.imf.org/external/pubs/ft/wp/2003/wp03112.pdf

Flood, R., and P. Garber, 1984, "Collapsing Exchange-Rate Regimes: Some Linear Examples,” Journal of International Economics, Vol. 17, No. 1, pp. 1-13.

Frankel, J., and A. Rose, 2002, "An Estimate of the Effects of Common Currencies on Trade and Income,” Quarterly Journal of Economics, Vol. 117, No. 2, pp. 437-466. , and _ 1998, "The Endogeneity of the Optimum Currency Area Criteria,” Economic Journal, Vol. 108, July, pp. 1009-1025.

Hendry, D., and B. Nielsen, 2007, Econometric Modeling: A Likelihood Approach (Princeton, New Jersey: Princeton University Press).

Hinds, M., 1999, Prepared Testimony for U.S. Senate Banking Committee, Hearing on Official Dollarization in Emerging-Market Countries. Available on the internet at: http://banking.senate.gov/99_07hrg/071599/hinds.htm , 2002, "Why Dollarize? The Case of El Salvador," Presentation at Summit of the Americas Center, March. Available on the internet at: http://www.americasnet.net/events/Dollarization/presentations/why_dollarizing.pps

Klein, M., 2005, “Dollarization and Trade,” Journal of International Money and Finance, Vol. 24, No. 6, pp. 935-943.

Krugman, P., 1979, “A Model of Balance-of-Payments Crises,” Journal of Money, Credit, and Banking, Vol. 12, No. 3, pp. 311-325. 
Lee, J., G. Milesi-Ferretti, J. Ostry, A. Prati, and L. Ricci, 2008, “Exchange Rate Assessments: CGER Methodologies,” IMF Occasional Paper 261 (Washington: International Monetary Fund).

López, T., 2001, “Elementos de la Política Monetaria en El Salvador Hasta el Año 2000,” Boletín Económico del Banco Central de Reserve de El Salvador, Vol. 14, No. 144.

Medina Cas, S., F. Frantischek, and A. Carrion-Menendez, 2011, "Enhancing the Effectiveness of Monetary Policy and Developing and Interest Rate Transmission Mechanism in Central America," unpublished manuscript.

Mojon, B., 2000, "Financial Structure and the Interest Rate Channel of Monetary Policy," ECB Working Paper No. 40 (Frankfurt: European Central Bank). Available on the internet at: http://www.ecb.int/pub/pdf/scpwps/ecbwp040.pdf

Mundell, R., 1961, “A Theory of Optimum Currency Areas,” American Economic Review, Vol. 51, No. 4, pp. 657-665.

Orphanides, A., 2007, “Taylor Rules,” Finance and Economics Discussion Series 2007-18 (Washington: Federal Reserve Board). Available on the internet at: http://www.federalreserve.gov/pubs/feds/2007/200718/200718pap.pdf , 2003, "Historical Monetary Policy Analysis and the Taylor Rule," Journal of Monetary Economics, Vol. 50, No. 5, pp. 983-1022.

Peterson, M, 1999, “Dark Horse Leads Race to Greenback,” Euromoney, May 1999, p. 22.

Rogoff, K., A. Husain, A. Mody, R. Brooks, and N. Oomes, 2004, Evolution and Performance of Exchange Rate Regimes. IMF Occasional Paper 229 (Washington: International Monetary Fund).

Rose, A., and T. Stanley, 2005, “A Meta-analysis of the Effect of Common Currencies on International Trade,” Journal of Economic Surveys, Vol. 19, No. 3, pp. 347-365.

Sachs, J., and F. Larraín, 1999, "Why Dollarization is More Straightjacket Than Salvation,” Foreign Policy, Fall 1999, pp. 80-92.

Schmukler, S., and L. Servén, 2002, "Pricing Currency Risk Under Currency Boards,” Journal of Development Economics, Vol. 69, No. 2, pp. 367-391.

Siklos, P., and M. Bohl, 2009, “Asset Prices as Indicators of Euro Area Monetary Policy: An Empirical Assessment of Their Role in a Taylor Rule,” Open Economies Review, Vol. 20, No. 1, pp. 39-59.

Swiston, A., 2010, "Spillovers to Central America in Light of the Crisis: What a Difference a Year Makes,” IMF Working Paper 10/35 (Washington: International Monetary Fund). Available on the internet at: http://www.imf.org/external/pubs/ft/wp/2010/wp1035.pdf

Taylor, A., and M. Taylor, 2004, “The Purchasing Power Parity Debate,” Journal of Economic Perspectives, Vol. 18, No. 4, pp. 135-158.

Taylor, J., 1993, “Discretion Versus Policy Rules in Practice,” Carnegie-Rochester Conference Series on Public Policy, Vol. 39, pp. 195-214.

Van Poeck, A., J. Vanneste, and M. Veiner, 2007, "Exchange Rate Regimes and Exchange Market Pressure in the New EU Member States,” Journal of Common Market Studies, Vol. 45, No. 2, pp. 459-485.

von Furstenberg, G., 2000, “A Case Against U.S. Dollarization,” Challenge, Vol. 43, No. 4, pp. 108-120.

Walsh, C., 2009, “Inflation Targeting: What Have We Learned?” International Finance, Vol. 12, No. 2, pp. 195-233. 